\title{
The Anatomy of Network Failure*
}

\author{
ANDREW Schrank \\ University of New Mexico \\ JOSH WHITFORD \\ Columbia University
}

\begin{abstract}
This article develops and defends a theory of "network failure" analogous to more familiar theories of organizational and market failure already prevalent in the literature on economic governance. It theorizes those failures not as the simple absence of network governance, but rather as a situation in which transactional conditions for network desirability obtain but network governance is impeded either by ignorance or opportunism, or by a combination of the two. It depicts network failures as continuous rather than discrete outcomes, shows that they have more than one cause, and pays particular attention to two undertheorized - if not undiscovered-types of network failure (i.e., involution and contested collaboration). It thereby contributes to the development of sociology's toolkit for theorizing networks that are "neither market nor hierarchy."
\end{abstract}

\section{INTRODUCTION}

When economic sociologists write about networks, they are frequently pursuing an agenda established by Walter Powell in the early 1990s. Powell recognized the growing importance of production arrangements "that resemble[d] neither the familiar alternative of arms' length market contracting nor the former ideal of vertical integration" (Powell 1990:299), and therefore challenged students of organizational behavior "to study and explain the circumstances under which cooperation and collaboration proceed with only limited reliance on contracts and the legal system, on the one hand, and on administrative fiat and bureaucratic routines, on the other" (Powell 1990:328).

Economic sociologists have risen to Powell's challenge in two ways. First, they have drawn a distinction between the formal analysis of network data in general and the analysis - whether formal or not - of network approaches to the coordination of economic activity in particular (Jones et al. 1997; Smith-Doerr and Powell 2005; Thompson 2003). Second, they have demonstrated that network arrangements are not mere "hybrids" of the markets and hierarchies that dominated the transaction cost approach popularized by Oliver Williamson $(1975,1985)$ but are "a distinctly different form” (Powell 1990:299) of economic governance. Thus, Joel Podolny and Karen Page (1998:59) define networks as collections of actors who pursue "repeated,

\footnotetext{
*Address correspondence to: Josh Whitford, Department of Sociology, Columbia University, MC 9649, New York City, NY 10027. Tel.: 212854 3593; E-mail: jw2212@columbia.edu. The authors thank Woody Powell, John Campbell, Fred Block, Gary Herrigel, Jonathan Zeitlin, Francesco Zirpoli, and the reviewers for helpful comments on various drafts of the article. We are also grateful to audiences at SASE, ASA, and the University of Modena Seminar on Political Economy for useful questions and comments on the argument in its early stages of development.
} 
enduring exchange relations with one another and, at the same time, lack a legitimate organizational authority to arbitrate and resolve disputes that may arise during the exchange." Examples include, but are not limited to "joint ventures, strategic alliances, business groups, franchises, research consortia, relational contracts, and outsourcing agreements" that are recognizably distinct from both market relations that are by definition "episodic" in nature and hierarchies that are necessarily governed by a "legitimate authority" (Podolny and Page 1998:59).

Economic sociologists have identified many concrete examples of network governance. They have shown, for instance, that networks of firms, labs, lawyers, and venture capitalists have made Silicon Valley into the envy of the world, and that the automobile industry has been transformed by the diffusion of Japanese manufacturing practices that blur the traditional boundaries between assemblers and their subcontractors. Biotechnology start-ups are fond of network arrangements, but so are publishers, filmmakers, and clothing designers, and economic sociologists therefore maintain that networks are particularly conducive to the governance of hightechnology and/or fashion-sensitive industries in which demand is unstable, interdependencies between tasks are complex, competencies are dispersed, and knowledge is rapidly changing (Jones et al. 1997; Podolny and Page 1998; Smith-Doerr and Powell 2005).

In short, in the 20 years since Powell's call for sociologists to develop a "conceptual toolkit" to describe networks that are "neither market nor hierarchy," that toolkit has been developed considerably. There is, however, one way in which the vast literature on network modes of transactional governance is glaringly and problematically incomplete: it lacks an overarching theory of failure.

This is not to say that nobody has noticed that networks fail. To the contrary, the existing literature is replete with evidence of their demise (Podolny 2001). Bruce Kogut (1989:187), for example, estimated that more than two-thirds of manufacturing joint ventures were terminated within a decade of their formation (see also Park and Russo 1996); the Boston Consulting Group concludes that well over half of the strategic alliances forged in the airline industry collapse (Economist 1995:60); and Sherrie Human and Keith Provan (2000:361) found that more than 60 percent of the small firm networks they studied in the mid-1990s had evaporated by 1998 . Such failures are even regularly invoked as evidence of the difficulty of forging and sustaining network governance - especially in high-value activities where resources, profits, and intellectual property are at stake (Harrison 1994; Podolny and Page 1998). And yet, though there have been sporadic calls for more explicit theorizing of "network failures" (e.g., Podolny and Page 1998; von Tunzelmann 2003:367, 2010:9), the sociological literature has to date generally sought only to explain the conditions under which network forms of organization are functional while largely ignoring what happens when those conditions do not obtain (Podolny and Page 1998).

The absence of a sociological theory of network failure is striking given that the literature in economic sociology on network forms of transactional governance has developed in explicit dialogue with Williamson and transaction cost economics. Williamson, after all, has been a primary foil not just in Powell's (1990) call for a new conceptual toolkit, but also in more general efforts to develop a "new" economic sociology (see, e.g., Granovetter 1985, 1990). And Williamson stridently argued that the analysis of governance is an intrinsically comparative exercise. He held it essential to work out "the powers and limits of both markets and hierarchies," and thus to put "market failure and organizational failure" on a par with each other 
(Williamson 1975:20-21; 1993:13). To do that, he drew on and extended Kenneth Arrow's (1970) distinction between "absolute" market failures, in which markets fail to form or disappear, and "relative" market failures, in which markets persist but underperform. He argued that the persistence or emergence of market governance where hierarchy would be more efficient (i.e., through bankruptcies) was a form of failure, but also noted that internal administrative "frictions" meant that hierarchies may themselves be exceedingly inefficient (Williamson 1975:20).

Sociologists have since drawn a parallel distinction between absolute and relative organizational failure. For instance, Meyer and Zucker (1989) studied "permanently failing organizations" and concluded that "efficient performance is only oneand not necessarily the most important-determinant of organizational survival" (DiMaggio 1989:9). The resources and preferences of organizational stakeholders are no less important and frequently conspire to ensure the survival of inefficient - that is, permanently failing - organizations.

The sociological literature on network forms of governance therefore suffers a lacuna. While sociologists tend to portray networks as a mode of transactional governance that is akin to - rather than an admixture of - markets and hierarchies, they have made no systematic effort to relate theories of network functioning to an understanding of the sources of network stillbirth and mortality, let alone to the conditions under which network governance persists despite poor performance.

In this article, therefore, we push Powell's agenda forward by developing a theory of network failure. We note that the simple absence of network governance is never per se a form of failure. Evidence that networks can succeed where both markets and hierarchies fail need not imply that network governance should be pursued in all instances; some (perhaps most) production and distribution is better pursued in either markets or hierarchies. But empirical evidence that network governance sometimes does not obtain at all and sometimes underperforms even in contexts where it would seem desirable suggests a need for a comprehensive framework within which to analyze similarities and differences between different types of network failure, differences that have until now been treated-if at all - in an ad hoc and isolated manner. We therefore provide a candidate framework that establishes the social conditions of network governance - that is, institutional safeguards against incompetence and opportunism - and distinguishes between two types of absolute network failures that occur in extreme cases of their joint absence or underdevelopment: (i) the breakup of already existing relationships, which we will refer to as network devolution; and (ii) the nonappearance of potentially profitable or productive networks, which we will refer to as network stillbirth. We then identify two varieties of relative network failure that occur when one-but not both-of the aforementioned safeguards is absent or relatively underdeveloped: (i) networks can "permanently fail" due to a lack of competencies, in which case we label the network involuted; (ii) or they can "permanently fail" due to opportunism, in which case we label the network contested. And, finally, we show that while each of these forms of network failure is in a sense distinct, they can nonetheless be usefully and systematically related to each other and to existing theories of network governance.

Our theory is particularly sensitive to the differences between-and differential consequences of-ignorance and incompetence, and it therefore contributes to the literature on network forms of organization in at least three important ways. First, by treating incompetence and opportunism as distinct - rather than parallel or redundant (Dorf and Sabel 1998; Rooks et al. 2000) - threats to network governance, we address not only the likelihood but the probable patterns of network failure. We 
are by no means the first scholars to realize that network governance presupposes trustworthy, competent exchange partners. In fact, the literature is replete with references to the importance of confidence as well as competence. But most scholars portray confidence and competence as overlapping, indistinguishable, or "mutually reinforcing" (Mellewigt et al. 2007; Sako 1992:43) values or attributes whereas we treat them as contingent and potentially-if by no means invariably-inimical to each other. Second, by clarifying both the limits and the powers of network governance, we guard against potential methodological problems including: (i) the risk of selection bias engendered by analysts who focus on successful networks to the exclusion of their stillborn or unsuccessful rivals (Appold 1995:28; Håkanson 2005:457; Tarrow 1996:396); and (ii) the risk of measurement error induced by analysts who at times implicitly treat organizational failure as the empirical manifestation of network failure, and thus conflate two potentially distinct processes (Stinchcombe 1962; Uzzi 1996; Zaheer and Mosakowski 1997). And, third, because we offer not only a typology of network failures but also a plausible account of their main causes, we generate new propositions that can guide future research and perhaps even inspire rival theories of network failure down the road.

The article is in three sections: The first section defines network failure, underscores the parallels between that definition and definitions of market and organizational failure, and lays out the assumptions and scope conditions of our theory. The second section develops our theory by introducing and defending four propositions with evidence drawn from the developed and developing worlds. And the final section discusses the implications of our theory and avenues for future research.

\section{DEFINING NETWORK FAILURE}

When we refer to network failures, we mean failure in a sense that self-consciously parallels what is meant in the literatures on market and organizational failure. In order to define the term, therefore, we begin with, but then tweak, a definition and an approach to definition that has its roots in a seminal 1958 paper ("The Anatomy of Market Failure") by Francis Bator. "What is it we mean by "market failure'?" Bator (1958:351) asked. He answered: "Typically, at least in allocation theory, we mean the failure of a more or less idealized set of price-market institutions to sustain 'desirable activities' activities or to estop 'undesirable' activities." ${ }^{1}$ His goal was to highlight that a market fails relative to some purpose-often but not necessarily the maximization of efficiency or welfare - and, simultaneously, to direct attention toward variation in the mechanisms driving those outcomes. Definitions of organizational failure have followed Bator's lead, with Meyer and Zucker (1989) defining organizational failure as a failure to achieve organizational goals and moving on to address the mechanisms and processes that allow organizations to persist despite inefficiency (or, following Barnard ([1938] 1968) rampant ineffectiveness). And Williamson (1975:9) went on to argue that governance failures are driven by the interaction of what he termed "environmental factors" and "human factors"-where by the former he largely meant transactional uncertainty and small numbers bargaining, and by the latter he meant that actors are boundedly rational and potentially opportunistic.

\footnotetext{
${ }^{1}$ Bator's (1958) paper is generally recognized as the first to use the term "market failure" and his work on the concept has been important in its subsequent development. Note that his use of the term "estop" was intentional if archaic. It does not mean "to stop" but rather "to plug up," and thus to impede.
} 
By analogy, what do we mean by network failure? Whereas prices constitute the principal "means of communication" in market relationships, social relations serve a similar function in networks (Powell 1990). By network failure, we therefore mean the failure of a more or less idealized set of relational-network institutions to sustain "desirable" activities or to impede "undesirable" activities.

We define the term in this way in order to mimic Bator by highlighting the normative considerations that make the issue of network failure important while simultaneously directing inquiry toward the distinct mechanisms by which network governance is - or is not-sustained. Our inquiry into those mechanisms engages the debate on network governance as it has since developed in dialogue with the work of Williamson. This means that, like most recent students of coordination failures, we follow Williamson in rooting those failures in the interaction between "environmental" and "human" factors. However, we consider those factors in light of a sociological literature that has not only clarified the particular environmental conditions under which network - rather than market or hierarchical-governance is desirable, but that also depicts actors as far more "socially embedded" than those found in Williamson's initial framework (see, e.g., Granovetter 1985; Podolny and Page 1998; Powell 1990). Before introducing our theory of network failure, therefore, we delineate the assumptions on which it is based. These assumptions are widely accepted in the sociological literature and are thus treated as premises rather than propositions.

\section{Environmental (Scope) Conditions}

By definition, forms of governance can fail only in organizational fields in which they are potentially desirable. We follow DiMaggio and Powell (1983:148) in defining organizational fields as "those organizations that, in the aggregate, constitute a recognized area of institutional life: key suppliers, resource and product consumers, regulatory agencies, and other organizations that produce similar services or products." Like them, we use it due to its relative neutrality regarding the proper unit of analysis: its virtue is that "it directs our attention not simply to competing firms, as does the population approach of Hannan and Freeman (1977), or to networks of organizations that actually interact, as does the inter-organizational network approach of Laumann et al. (1978), but to the totality of relevant actors" (DiMaggio and Powell 1983:148).

The relative desirability of particular governance modes in particular organizational fields is obviously subject to debate. But the governance literature treats efficiency and innovation as primary criteria of success. We therefore sidestep that debate and accept the transactional conditions that make particular governance mechanisms potentially efficient or effective as the scope conditions for theories of governance failure. For example, Williamson suggests that market governance is particularly functional for the production and distribution of goods that are highly standardized, in which case the number of potential transactors is high, or confront stable demand patterns, where uncertainty is low; an absence of market governance in the presence of those transactional conditions therefore represents a failure, since market governance would have been most efficient. Similarly, firms are advised to abandon markets for in-house production when their demand for an input is high, the number of available suppliers is low, and the alternative is exposure to "hold up" by opportunistic suppliers who hope to take advantage of their positional power to renegotiate the terms of exchange ex post facto (for reasons we delineate in greater 
detail below). In these circumstances, a failure to pursue in-house production would in all likelihood constitute an organizational failure (Williamson 1975).

By way of contrast, network governance is held functional in organizational fields characterized by a combination of unstable demand and either rapidly changing knowledge or complex interdependencies between component technologies. These characteristics are common to craft-based industries like clothing and construction that serve unstable and highly differentiated demand segments, and that therefore place a premium on flexibility and the rapid reconfiguration or resources; knowledgeintensive industries like biotechnology that confront rapid and unexpected shifts in competencies as well as market conditions; and autos and aerospace, whose final products are complicated and highly integral (Brusoni and Prencipe 2001; SmithDoerr and Powell 2005). In short, we neither need nor want networked organizations to make our office paper or telephones. We may, however, want networked actors to develop our environmentally friendly pulping mills (Kivimaa and Mickwitz 2004) and our next-generation smartphones (Sabel and Saxenian 2008). Only when network governance is simultaneously desirable in light of transactional conditions and absent (or underperforming) should we think of a network as "failing."

\section{Social Conditions}

Williamson (1975) made clear that governance failures of any kind cannot be purely caused by environmental conditions: absent ignorance (i.e., bounded rationality), complete contracting would be unproblematic; and absent opportunism (i.e., selfinterested behavior with guile), contracts would be unnecessary. These two points are widely accepted in a sociological literature that similarly holds that parties to repeated, enduring exchange relations must forgo some exit rights even though doing so exposes them to hold up by predatory exchange partners who control key assets, and that is also well aware that ignorance is no less threatening to network governance than is opportunism. When transactions are complex and the services or goods to be obtained are not well specified, after all, exchange partners need to know not only whether their interlocutors will be willing, but whether they will in fact be able, to deliver on their promises - that is, they need to worry about bad deals made in good faith by actors who were simply unaware of gaps between competencies in the network and industry-wide best practices. That literature, however, has also broken with Williamson's depiction of ignorance and opportunism as intrinsic to all production and exchange.

This break - the importance of which we cannot overstate - came most notably with the publication of Mark Granovetter's (1985) critique of Williamson's "undersocialized actors" in an article on the embeddedness of economic action. According to Granovetter (1985:494), Williamson had failed to recognize that the dyadic relations at the center of his theories are themselves "embedded in broader systems of social relations," and that his theories and followers therefore could not incorporate the implications of the fact that the ways in which opportunism and ignorance affect those transactions is a function of a social overlay. The logic of that critique has since been developed in work by Krippner (2001) and Block (2003) (with an approach validated in a concurrence by Granovetter; [see Krippner et al. 2004]). It argues that all economic activity - and not just network governance - is embedded in social relations, and that social relations are more generally shaped by social institutions. In this article, we thus refer to "social conditions" rather than to "human factors." 


\section{A GENERAL THEORY OF NETWORK FAILURE}

A theory of governance failure must follow from, and be related to, a broader theory of governance functionality. The literature on network governance has paid attention not only to the environmental conditions that render collaboration desirable but to the social and institutional conditions that make collaboration possible. We thus offer our first proposition.

Proposition 1. Ideal-typical networks presuppose: (1) an organizational field characterized by a combination of unstable demand and either rapidly changing knowledge or complex interdependencies between component technologies; and (2) the embedding of economic activity in social institutions that simultaneously engender a continuous search for new information and safeguards against opportunism among existing or potential exchange partners.

Widespread efforts to document "repeated, enduring exchange relations" lacking "a legitimate organizational authority to arbitrate and resolve disputes [arising] during the exchange" (Podolny and Page 1998:59) began in earnest in the late 1970s and early 1980s in the wake of changes in the global economy that made those relations far more common (Dore 1983; Piore and Sabel 1984; Streeck and Schmitter 1985). Those efforts notably led Williamson (1985:83-84) to revise his own view that the distribution of governance forms was bimodal-that is, "thick" in its market and hierarchical tails - and to instead recognize that "hybrid" transactions were more common and perhaps stable than he had previously recognized (Williamson 1975). Much early theorizing of those exchange relations relied, however, on either an over- or undersocialized conception of the actor (Granovetter 1985). Some pointed to the prominence in the debate of examples drawn either from Japan or from particular regions - called "industrial districts" - in Italy to argue that the propensity to collaborate in those regions was rooted in a primordial trust (Amin and Robins 1990; Dore 1983). Others used game theory to depict repeated, enduring exchange relations as a mere consequence of reputation effects and the shadow of the futurethat is, as the equilibrium result of a repeated prisoner's dilemma (Hill 1990). The sociological literature, by contrast, rooted network governance in a complex ethics of exchange sustained by social and political institutions that simultaneously-and interactively_-generate trust and competence (or, inversely, mitigate opportunism and ignorance).

Sebastiano Brusco, for example, challenged those who would ascribe the cooperative ethic underpinning collaboration in the industrial districts to the notion that "Italians are easy-going people who like working together" (cited in Natali 2007:204). Rather, Brusco (1982, 1999:22) argued, firms in the districts interpret each others' actions through the lens of "rules of the game" that are not simply the laws of contract but that instead lie in a set of understandings and practices explicitly propagated, legitimated, and enforced by business associations, unions, and other regional institutions. These rules mitigated opportunism, since "two agents who work together on a continuous basis will never fully take advantage of the market power that is available to them." But they simultaneously addressed the problem of ignorance because those who work together regularly "will take into consideration the survival needs and success opportunities of the other; both are tied to profit margins, and to the ability to keep their respective technological standards high and to retain the best and most skilled workforce" (Brusco 1999:22). 
Brusco's depictions of network governance in Italian industrial districts are especially explicit in his documentation of a virtuous interplay between social conditions that simultaneously ensure trust and competency. Similar claims, however, are common in theories of network functionality. Brian Uzzi's (1997:61) discussion of "embedded" ties in the New York garment district, for example, relies on descriptions of a "unique logic of exchange that results from the distinct social structure of organization networks and the microbehavioral decision-making processes they promote." That logic, he writes, generates a governance structure characterized by "heuristic and qualitative decision rules" that not only lead "calculative risk and monitoring systems [to] play a secondary role," but also encourage "fine-grained" information transfer and "joint problem-solving arrangements [that] promote voice rather than exit" and create opportunities for mutual learning (Uzzi 1997:61).

Take also Charles Sabel's descriptions of the diffusion of "learning-by-monitoring" (Helper et al. 2000; Sabel 1994). Sabel and his colleagues argue that the many giant manufacturers who have begun to navigate the uncertainties of deeply fragmented markets by decentralizing production have frequently recognized that this in turn gives them greater incentives and opportunities to learn not only from but about their suppliers-who, for their own part, are then encouraged to learn from and about their customers as well. Because federation has left these firms unable to determine what to build and how best to build it without help from others, they have been building new institutional mechanisms, including innovative forms of contracting, that force multiple parties to (monitor) each other's relative competencies as they explore what to do next (Gilson et al. 2009). And because this monitoring facilitates the construction and search for competencies, it is more acceptable to parties aware of their own ignorance. It thus avoids the wariness that tends to follow more calculative safeguarding against opportunism and has the welcome side effect of allowing the parties to glean clues about each other's reliability along the way. This generates a sort of "studied trust" (Sabel 1993), as the parties' initial experimentation with positive-sum collaboration paves the way for new experimentation down the road.

Finally, Schrank's (2005:53) discussion of the "inseparability of production and marketing" in the international apparel trade similarly underscores the reciprocal relationship between confidence and competence as well as their growing relevance in the era of global production. While developing country apparel producers have to "demonstrate their willingness and ability to meet exacting price, quality, and delivery standards before they can develop stable, informative relationships with foreign buyers, they need to develop stable, informative relationships with foreign buyers if they are to learn how to meet the price, quality, and delivery standards in question" (Schrank 2005:53). Northern apparel buyers like Nike, Target, and the Gap face a parallel dilemma, however, for they "must find trustworthy, reliable suppliers before they can source from overseas, but they must devote time, energy, and not infrequently capital to untested relationships with unknown partners before their suppliers are deemed trustworthy and reliable" (Schrank 2005:53). Network production is often inaugurated, therefore, by exchange partners who have preexisting or ongoing social relationships; but its growth and continued viability are premised on continued monitoring and exchange of productive information.

Our understanding of network functionality, in short, holds that network governance is desirable in organizational fields characterized by unstable demand, dispersed competencies, complex interdependencies, and fast-paced change, so long as there are sufficient institutional safeguards against ignorance and opportunism. Our second theoretical proposition thus follows from the first. 
Proposition 2. Absolute network failures occur when social institutions generate an interaction of ignorance and opportunism among potential exchange partners in organizational fields characterized by a combination of unstable demand and either rapidly changing knowledge or complex interdependencies between component technologies.

There are two reasons to so explicitly state the conditions under which absolute network failures occur. First, it underscores that we live in an "always embedded" economy. Network failures therefore do not occur only when there is an absence of network governance. They are better understood as a peculiar sort of presence, as something that occurs when network governance is potentially functional but is impeded by extant social and institutional conditions. Second, understanding network failures in these terms allows us to differentiate among them. Even when we are talking about absolute failures it is useful to differentiate, for example, between network devolution and network stillbirth. The former refers to cases in which transactions once fruitfully governed by network "devolve" to market or hierarchical governance - which is what is usually meant by those theorists who have recognized that networks fail. The latter instead captures situations in which efforts to foment network governance never even got off the ground.

Examples of stillbirth are not easy to find - not because stillbirth is uncommon or unimportant, but because it is hard to study. The relevant population is, after all, indeterminate. Still, they are not completely unknown to the literature. Take, for example, the growing body of scholarship that asks why there is "no Silicon Valley" in Europe, Japan, Australia (Cooke 2000; Hospers 2006; Leslie and Kargon 1996; Marceau 2005; McLaughlin 1999) — or, for that matter, New Jersey. While the so-called Research State (Pierce and Tressler 1964) traditionally played host to dozens of high-technology firms and corporate laboratories, it had to import twothirds of its Ph.D.-level scientists and engineers from states with better universities at substantial cost. As the prospect of competition from "regions with better access to research universities" (Leslie and Kargon 1996:443) mounted in the 1960s, therefore, a consortium of New Jersey firms and educators hired former Stanford provost Fredrick Terman, the acknowledged "father of Silicon Valley" (Branch 1985), to replicate his achievements back east. The results are by now well known. "The venture failed," according to Mansel Blackford (2007:70), "when the companies and the educational facilities proved unable to cooperate. New Jersey's high technology firms developed, as a consequence, more as individual companies than as part of an industrial district." 2

Examples of network devolution, by contrast, are commonplace. We noted several in our introduction (i.e., the frequency with which strategic alliances fail). Others would include, for instance, the 1998 alliance of Daimler-Benz and Chrysler, which was touted not just as a "merger of equals" but also seen as likely to generate efficiencies for Daimler and innovations for Chrysler (Hughes 1998). Instead, that alliance quickly unraveled, devolving first to hierarchy as Daimler's managers took control due to their contempt for competencies at Chrysler and reluctance "to see the makers of Mercedes associate with the makers of Dodge." And this in turn led to a lawsuit by Chrysler shareholders who accused Daimler's managers of misleading investors as to their true intentions at the time of the merger's origin. The players

\footnotetext{
${ }^{2}$ See also Leslie and Kargon (1996), as well as Adams (2003:540), on the "corporate culture of mistrust" that undermined Terman's effort to build "Silicon Valley East."
} 
eventually returned to market governance as Daimler unwound the acquisition to Cerberus Capital Management in May 2007.

Network devolution need not lead to market governance, however, but may instead be followed by the creation or expansion of hierarchies. David Stark (1996), for instance, anticipated the birth of a "distinctively East European capitalism" that self-consciously embraced "a network-centered approach in which not markets, nor states, nor isolated firms but social networks are the basic units of analysis" (Stark 1996:1017; see also Stark 1993:303). "When the future is highly uncertain," he wrote in the mid-1990s, "it is far from clear at T1 whether your assets will be interdependent with mine at $\mathrm{T} 2$. In such situations, in addition to the dualism make or buy (hierarchy or market) there is an alternative-cooperate" (Stark 1996:1021). Yet while there is evidence that some of those networks have made the transition from mixed state-private ownership networks to mixed foreign-domestic ownership (Stark and Vedres 2006:1393), many were eventually "consolidated" under the control of foreign capital and thus have essentially devolved to hierarchy despite the seeming functionality of network modes of governance. Lawrence King (2001), for example, shows that multinational corporations purchased many of the most valuable enterprises in Eastern Europe and hired their former managers, thereby abandoning collaborative arrangements for lucrative employment contracts designed in part "to eliminate the incentive for opportunistic behavior by managers before their control is firmly established" (King 2001:502). Safeguards of this sort, King argues, have often been the preferred solution for foreign capitalists buying into economies with modest competencies (e.g., "relatively cheap, but skilled and educated, labor" (King 2001:535)) where confidence is decidedly lacking.

Stillbirth and devolution thus mark different types of absolute network failure. Network failure, however, need not be absolute. There is evidence that a paucity of competence and/or trust does not necessarily threaten the basis of network production, and that there is a middle ground in which collaborative arrangements persist yet underperform. We thus offer our next proposition.

\section{Proposition 3. Networks sometimes fail in relative terms, and relative network failures are differentiated by origin and consequence.}

If the network form is to be more than a bastard offspring of market and hierarchy, failures cannot reduce in all cases simply to one or the other. If the network is in fact a distinct mode of governance network failures must be more than the absence of network governance, and networks, like markets and organizations, must be able to fail in relative as well as absolute terms. A theory of network failure must therefore account for the partial - as well as the existential - threats to their performance. However, because the literature on network governance has developed in response to Williamson's focus on alternative governance arrangements (see, e.g., Williamson 1991), and has therefore taken the existence (and implicitly the absence) of network governance as its explanandum, the question of relative network failure has scarcely been broached. There is recognition, as we have noted, that networks fail, and there is even recognition that these failures may be due to opportunism and ignorance; but there has been little systematic study of situations in which opportunism and/or ignorance are present but not paralyzing.

On the contrary, the existing literature tends to conflate opportunism and ignorance and to treat them as indistinguishable when it comes time to talk of failure. 
For example, Michael Dorf and Charles Sabel portray (1998:308, emphasis added) "the fear of engaging an incompetent or unreliable partner" as the biggest obstacle to the emergence of decentralized production without drawing a distinction between the two. Gerrit Rooks (2000:127, emphasis added) and his collaborators also assume that a firm will "tend to exit from a relation with a partner who turns out to be incompetent or unreliable." And John Hendry (2002:99) admits that "the problem of limited competence is not recognized in agency theory at all, for a simple reason. Given the utility functions of principals and agents, the effects of self-interest can be formally modeled, but those of incompetence, which could act unpredictably in any direction, cannot." Ironically, however, Hendry goes on to argue that the possibility of "honest incompetence" does nothing to alter the basic tenets of agency theory, for "the essence of agency relationships lies not in the motivations or competence of the parties involved, which may vary from case to case, but in the delegation of authority from principal to agent, as a result of which responsibility for the conceptualization, interpretation, and expression of objectives is divided between two or more people" (Hendry 2002:107).

We disagree. While the essence of an agency relationship may well lie in the delegation of authority, as Hendry argues, the effectiveness of such a relationship presupposes competence as well as trust. This became clear to us in our independently conducted interviews with buyers and suppliers of durable and nondurable goods like auto parts, machinery, and apparel over the course of the past decade. When we asked why various relationships underperformed or went belly up, our respondents sometimes used colloquial expressions like "he screwed me" or "they screwed up." But there is a notable and interesting, if subtle, difference between "screwing" your exchange partner and "screwing up." The former necessarily implies opportunism. The latter need imply nothing more than a lack of competence or inability to solve a joint problem. When asked to clarify which of the two labels applied in which particular case, however, our respondents would often demur, and would thereby conflate ignorance and opportunism no less than had their academic observers. After all, our respondents could not say with any certainty whether they had been victims of competency shortfalls or deliberate self-dealing and in their eyes it didn't matter. Either way, they had to find new parts, new processes, or perhaps even new exchange partners (Schrank 2004, 2005; Whitford 2005).

While the conflation of opportunism and ignorance is perhaps immaterial to those who want to understand why particular relationships go bust, it poses an enormous obstacle to the development of a general theory of network failure. If we want to understand network failure as a sociological phenomenon, the difference between screwing and screwing up matters enormously.

Opportunism tends to arise where informal or formal institutions fail to nourish trust, confidence, and loyalty and is likely to dissipate where norms of reciprocity and good faith are pervasive. Kinship relations, ethnic networks, and religious communities have frequently been portrayed as bulwarks of community and reciprocity. And there are many others, including political parties, trade associations, and labor unions, that are potentially more susceptible to policy intervention.

Competency shortfalls, by contrast, tend to emerge where formal and informal institutions fail to align company strategies or foster the growth of skill and technical capacity. They are less likely to emerge where productive assets-broadly definedare widespread. Strategic alignment, skill, and technical capacity are frequently fostered by the same organizations and institutions that build trust - that is, trade associations and labor unions - but they are also the products of public institutions 
like schools, vocational and training institutions, development banks, and industrial extension services.

Why draw this distinction? Recognizing differences in types of network failure guards against the obvious temptation to treat failures as straightforward products of bounded rationality. Real rationality is bounded, of course, but bounded by what? By specifying the principal constraints on rationality - an inability to recognize and distinguish between failures that are fundamentally products of opportunism on the one side, and those that are ultimately rooted in the systemic ignorance of relevant competencies on the other-the distinction identifies the network analogs to both the "permanently failing organizations" described by Meyer and Zucker (1989) and the "relative" market failures discussed by Arrow (1970).

Relative network failures of different types are products of deficits of different safeguards. Involution occurs where there are institutional safeguards against opportunism but where exchange partners have for one reason or another become overly dependent on each other and therefore fail to absorb information from outside the network-information they need to maintain their competencies in a world of intense innovation and competition (Geertz 1963; Grabher 1993; Uzzi 1996, 1997). Contestation occurs where the organizational field is endowed with desirable competencies but exchange partners lack safeguards against mistrust, miscommunication, and opportunism, leading them to monopolize information in ways that undermine their ability to jointly compete in the uncertain and fast-moving markets to which network governance is ostensibly best suited (MacDuffie and Helper 2006; Whitford 2005; Whitford and Enrietti 2005; Whitford and Zeitlin 2004). We therefore address the problem of relative network failure by introducing two subsidiary propositions.

Proposition 3a. Involution is a product of competency shortfalls that are produced by isolation from - and resolved by efforts to absorb and disseminate-productive knowledge.

Our understanding of network governance presupposes that network participants are ultimately involved in information processing (Stinchcombe 1990). Whether they are designing women's wear in New York, writing software for a new videogame in Tokyo, or machining engine components for an automaker in Mexico, they are in essence putting information to use. Members of an ideal-typical network therefore have ready access to the relevant information without which even the most transparent or loyal exchange partners would suffer competency shortfalls.

We label networks that are relatively free from opportunism but that lack key productive information involuted networks. Involuted networks suffer from a paucity of competence rather than a paucity of confidence. And in the best known cases their competency shortfalls are, ironically, products of their loyalty.

Take, for example, the industrialists described by Gernot Grabher (1993) in his analysis of "the weakness of strong ties" in the Ruhr Valley. This heartland of the German coal, iron, and steel complex suffered greatly in the late twentieth century, as the industry was rocked by demand shortfalls, plant closings, and unemployment. While local observers blamed the crisis on the end of postwar reconstruction, the growth of foreign competition, and the declining income elasticity of demand for steel, they were unable to account for the region's failure to redeploy resources into new sectors and activities. Grabher resolved this puzzle by recognizing that the crisis was fundamentally regional and thus only contingently sectoral. 
Grabher argued that the tightly coupled Ruhr Valley industrialists suffered from three distinct network lock-ins. First, they were "functionally" locked into interpersonal relationships with their exchange partners (Grabher 1993:260). Core firms shared their investment plans with their local suppliers and the latter therefore dispensed with "boundary spanning functions" like research, development, and marketing activities designed to attract new customers. Second, they were "cognitively" locked into a "groupthink" mentality (Grabher 1993:262). They viewed all crises as cyclical rather than secular and therefore ignored the need to redeploy assets out of coal, iron, and steel and into more sustainable activities over time. And, finally, they were "politically" locked into the government of North Rhine-Westphalia. Capital, labor, and their political representatives developed "a strong alliance supporting the coal, iron, and steel complex" and thereby inhibited a "timely reorganization of the Ruhr" (Grabher 1993:264).

Grabher labels the "pathological homeostasis" that results from such lock-in "involution" and holds it responsible for the Ruhr Valley's delayed and costly adjustment. Others have identified similar dynamics in distinct industrial and national contexts. For instance, Sabel (1994:144) argues that a focus on static rather than dynamic benchmarks caused Japanese information technology and machine tool suppliers to get "better and better at a losing game" in the late 1980s. "Improving faster than IBM on what IBM was doing when it dominated its industry [was] plainly no longer a world-beating strategy when IBM [was] no longer dominant" (Sabel 1994:144). Similarly, Janine Nahapiet and Sumantra Ghoshal (1998:260) argue that "organizations high in social capital may become ossified through their relatively restricted access to diverse sources of ideas and information." Brian Uzzi (1996) gives their hypothesis added credibility by identifying a curvilinear relationship between the "embeddedness" of buyer-supplier interactions and individual supplier mortality in the New York apparel trade. And Bill McEvily and Alfred Marcus's (2005:1051) survey of 234 job shop manufacturers revealed that "capability acquisition was lower when a firm was highly dependent on its lead customer for sales."

Such findings can be accounted for in some cases by Grabher's notions of functional and cognitive lock-in. Uzzi's apparel contractors and McEvily and Marcus's component suppliers, for example, are locked into particular relationships with particular buyers who espouse and reproduce particular worldviews. But contractors and suppliers may also fall victim to the "political lock-in" that derives more from strong ties to public officials than from the functional or cognitive lock-ins that are produced by (and in conjunction with) their exchange partners. Take, for example, Schrank's (2005) analysis of apparel suppliers in the Dominican Republic. While established manufacturers in the capital of Santo Domingo reaped the rewards of government protection and subsidy in the mid-twentieth century, and therefore resisted the onset of globalization in the 1980s, their arriviste challengers in the secondary city of Santiago had traditionally been denied government support, and therefore carved out a place for themselves on the global assembly line and assumed pride of place in the country's manufacturing economy by century's end.

Nor is the Dominican Republic exceptional. Manufacturers throughout the developing world are learning that protection has costs as well as benefits. For example, the Mexican furniture manufacturers studied by Piore et al. (2001) forged and exploited strong ties to Mexico's dominant party during the era of import-substituting industrialization, but found themselves caught off-guard and largely unprepared when trade and political liberalization arrived in the late twentieth century. While they expected their low labor costs to give them a foothold in the North American market, 
and tried to build bridges to foreign buyers, they ultimately lost even their own market to low-cost Asian imports-with little to no compensatory market expansion north of the border.

Why were the Mexican furniture makers unable to take advantage of globalization? According to Piore et al., the problem was that they knew nothing about North American tastes and styles and had trouble adapting to northern quality standards. Manufacturers often blame a lack of capital for their travails. "But as one of the managers explained" to Piore and his associates, "it is no more expensive to produce a relatively high quality piece of furniture than a low quality one" (Ruiz Durán 1998). One can only do so, however, if he or she knows what constitutes "quality" in the new market, and how to get there, and one doesn't learn these things when one is locked into the old market.

Ignorance is sometimes addressed by organizations that provide education and training including not only vocational and technical schools but also management consulting firms, industrial extension agencies, joint venture partners, and supplier development programs. The necessary information, however, must be incorporated into the network before it is too late. The Mexican furniture makers did eventually turn to North American consultants, but only after a cluster of 3,000 small and medium-sized enterprises had been reduced in size by two-thirds. In the Dominican city of Santiago, by contrast, apparel makers pooled their resources early, hired a New York representative, and lured foreign partners who served as "tutors" in the 1970s and 1980s (Schrank 2005). As foreign competition intensified in the early 1990s, they found their cost advantages slipping away, and they therefore started to exploit publicly subsidized training programs designed to disseminate best practices (e.g., modular production, full package production, etc.) throughout their industrial estates (Schrank 2011). This differentiated Santiago from the involuted Dominican capital of Santo Domingo where manufacturers have been less likely to exploit the opportunity for vocational education and training. While publicly sponsored training programs are by now found throughout the country, and are therefore available to apparel makers in Santo Domingo as well as Santiago, their enrollments and impact have been decidedly higher in the latter than the former (Schrank 2011). In fact, the industrial estates found in and around Santiago not only play host to more training courses than their rivals in the capital on an annual basis but simultaneously boast longer courses with more intensive curricula.

The problem is thus less the absence of a formal institution than the lack of informal norms and incentives that would predispose Santo Domingo suppliers to exploit formal regional institutions. Why would rational entrepreneurs avoid potentially beneficial programs? Schrank (2005) traces the answer to the capital's traditional isolation from world markets. The capital's manufacturers have traditionally had a politically reinforced stranglehold on the protected, and lucrative, local market and have therefore resisted the onset of globalization. An effective government response would thus aim not so much to create training programs in the capital as it would convince the capital's producers to take advantage of training programs and the broader array of institutions designed to facilitate - rather than resist-globalization.

This is precisely where the glass in Santo Domingo is half full rather than half empty - and where it matters that this is a partial network failure. After all, the capital is not entirely devoid of the social requisites of network production. Santo Domingo producers have traditionally been isolated from the wider world. They lack competencies, but they are tightly coupled to each other. This gives them a social foundation on which to build. If they could use their cohesion not to resist but 
to embrace globalization, they might well build better relations with foreign buyers, develop new skills and capacities, and thereby enter a virtuous circle of confidence and competence akin to the one found in Santiago.

The implications are clear and extend well beyond the Dominican Republic. Potential suppliers that have been isolated from world markets for years not only need to learn, which they can do through industrial extension and training programs. They also need to "learn to learn" (Levitt and March 1988:332), which is arguably more difficult - especially for large or privileged producers who have traditionally been able to sidestep competition and search. It follows that government efforts ought to focus not only on creating viable training programs but also on encouraging potentially ignorant or wary employers to use them. Recognizing that producers in partially failing networks by definition have something to build on helps to identify relevant carrots (e.g., specific subsidies) as well as sticks (e.g., de-protection).

Proposition 3b. Contested collaborations are products of opportunistic behavior among otherwise competent partners and are resolved by confidence-building institutions.

Our understanding of network governance presupposes not only that network participants are involved in information processing (Stinchcombe 1990) but that participants in ideal-typical networks have access to - and are willing to share-information about their partners' abilities. This gives them the ability to locate complementary competencies and drives them toward faster-changing and more uncertain demand segments.

But what happens when networks rich in competencies suffer a paucity of confidence? Certainly, vicious cycles that generate network stillbirth or rapid breakdown can occur. But full devolution to market or hierarchy is by no means guaranteed. Indeed, recent scholarship depicting changes in the organization of manufacturing industries has shown that transacting parties may well find themselves caught instead in ongoing underperformance traps - that is, in partial network failures - driven by an interaction of low trust and high, but dispersed, competencies.

MacDuffie and Helper (2006:419), for example, document the emergence of what they term "collaboration without trust" in the American automotive industry. When the industry began to abandon vertical integration in the 1970s, they write, its "initial focus" was the "growing gap between wages and benefits at the automakers' in-house parts divisions (which were unionized) and [those] at non-union independent suppliers." But subsequent decisions to outsource design tasks as well have encouraged a more strategic approach to outsourcing in which the automakers "rely on specialized supplier expertise, rather than maintaining that expertise in-house, while also reducing labor costs."

On the face of things, MacDuffie and Helper (2006:428) argue, this has been driven by demands for quality and "the higher-costs (both perceived and real) of vertically integrated suppliers and the persistent integrality of vehicle product architecture." It thus ought to drive more explicit "coordination and collaboration on design and production" between automakers and their suppliers. However, they write, this has been tempered by global overcapacity and automakers' access to "newly sophisticated suppliers in less-developed countries" that have reinforced "U.S. automakers' longstanding purchasing routines built around exit" (MacDuffie and Helper 2006:420). A surprising split therefore emerged not only within the industry, but internal to particular automakers. Collaboration is more successful when "it takes forms that allow for the emergence of trust over time" (MacDuffie and Helper 2006:454). But 
"some firms, especially in the United States, collaborate on certain core engineering, manufacturing, and product design tasks while at the governance level, where suppliers are selected and contracts are written, there is an adversarial relationship and lack of trust" (MacDuffie and Helper 2006:420).

This raises a question. If collaboration without trust-or, in our terms, the contested network - is suboptimal, why is it stable? The answer, MacDuffie and Helper argue, lies in the fact that partners have gotten locked into "task-level collaboration" because they have outsourced design to a degree that no single party is still able to develop workable products alone; they simply lack the competencies. At the same time, their purchasing departments are imbued with legacies of exit, and they are enmeshed in a system of corporate governance that generates immense pressures to meet short-term targets (Hall and Soskice 2001b). They are trapped, in short, in a vicious circle caused by an intersection of organizational dynamics and institutional legacies.

This intersection is explored in detail in Whitford's (2005) account of "contradictory collaboration" in durable manufacturing industries in the American Upper Midwest. Whitford takes as his starting point Powell's (2001:63, 65) observation that the "reception and diffusion" of the "new logic of organizing" has been a "complex story," especially for companies and regions where entrenched hierarchy and arm'slength relations were "at one time a recipe for success" and where there is thus "both more resistance to new ways of doing things and greater difficulty in creating novel practices than in a new organization built from scratch." But Whitford also explores the microdynamics of that complexity, and concludes that the partiality of the new logic of organizing in American durable manufacturing is not transitional but stable absent government intervention (see also Herrigel 2004).

Whitford, like MacDuffie and Helper, finds that large manufacturers have devolved substantial production and design responsibilities to their suppliers. But he also emphasizes that the move toward vertical disintegration in historic American manufacturing regions has reoriented the industrial structures of those regions. Over time, in the hopes of capturing the gains from decentralization, these companies have-both through attrition and through active supplier development-encouraged a substantial transfer of competencies and personnel to their armies of smaller suppliers. This has effectively locked them into a production model in which they must collaborate to some degree with those suppliers if they are to produce workable machines. But it has not mitigated that they face so much market and technological uncertainty that they are not sure what sorts of collaboration are required, nor has it altered legacy relationships and organizational structures designed to inhibit rather than foster the growth of collaborative relationships between purchasing agents and suppliers (Whitford 2005).

Purchasing agents are commonly promoted, for example, for successfully cutting costs. But in light of the fluid career structures found in America's "liberal market economy" (Hall and Soskice 2001b), those promotions create perverse incentives for particular managers to seek short-run cost savings at the expense of long-term relationship-specific investments - so long as the difficulties thereby produced can be "outrun" by those savvy enough to climb the corporate ladder before their decisions bear bad fruit. Aggressive cost-cutting, meantime, creates still more perverse incentives, this time for those managers' counterparties - the suppliers. In a world of hard bargaining and short time horizons, suppliers often prefer to invest only minimally in new product development - given mere promises of business down the line-and instead hoard process information, monopolize skills, and treat their partners with 
caution. The consequences are predictable. Suppliers make a show of collaborating, but in fact muddy the waters with misleading or even deceptive cost information, or they forego offers of concrete assistance from their customers for fear of compromising information - even as this makes it riskier for their customers to depend on them and undermines the regeneration of the competencies that had led those customers to rely on them in the first place.

Given that most agree that some collaboration is required in such industries, but that there is disagreement over how much and with whom, the unsurprising result of this "hedging" by suppliers has been to reduce the returns to collaboration. This in turn enhances the position in customer firms of those who believe that the best way to lower costs is to jump from underbidding supplier to underbidding supplier to take advantage of excess capacity in global markets. The tactics of those "marketeers," however, do run up against the relative irreversibility of decentralization in a world in which technologies have changed so rapidly that in-house production is in many cases no longer an option. We therefore find an organizational field in which companies' desire to capture returns in innovative market segments has led them to modify their organizational structures as they chase lucrative but unstable segments in demand in which knowledge changes rapidly and there are complex interdependencies between component technologies. They have as a result gotten locked into a strategy premised on a modicum of collaboration even as they are rife with organizational routines better suited to the resolution of what Brusoni et al. (2001:618) euphemize as "appropriability" concerns. The result, in short, is that American durable manufacuring has the decentralized structure and diffuse competencies required for network governance, but an inability to generate virtuous circles in which shared competencies underpin trust, which in turn underpins further joint exploration of competencies. The relevant players are simply trapped in a form of network governance that can underperform for considerable periods of time yet devolve neither to market nor to hierarchy.

Such contested networks are especially likely to occur in American durable manufacturing, enmeshed as it is in a deeply partial transition to Powell's (2001) "new logic of organizing." But they are by no means exclusive to that country or sector. Fiat's Italian supply networks are awash in contested collaboration (Whitford and Enrietti 2005). And contestation is the rule-rather than the exception-in the decentralized production of many nondurable consumer goods as well (Berling 1993; Hays 2001).

The more fashion-sensitive segments of the apparel industry provide a particularly apposite example. Apparel retailers not only penalize their suppliers for manufacturing and delivery errors but demand financial compensation (i.e., "markdown money") for discounted and unsold merchandise. Suppliers respond to their demands by denying responsibility for the problems, taking precautionary measures, and passing the added costs along to their subcontractors and customers (Bird and Bounds 1997; Shields 2009). And the dense networks of merchants, manufacturers, and middlemen that underpin the needle trades are therefore distinguished less by the "reciprocal, preferential, mutually supportive actions" described by Powell (1990:300) than by the ongoing "tug-of-war over margins and competing goals" (Chain Store Age 2003) that Robert Berling has referred to as "the squeeze-the-supplier approach, in which total costs are not reduced but merely shifted from one company to another" (Berling 1993; see also Agins 2006 for a revealing discussion).

Apparel network failures are likely to be partial, however, for retailers and suppliers still "need each other" (Danaher 2006) in myriad ways. Retailers need to stock 
their shelves with large volumes of stylish garments on short notice. Suppliers need marketing outlets and promotional expertise for their wares. And neither party is inclined to assume the risk of vertical integration (Shields 2009). Mistrust is therefore mediated - if by no means mitigated - by "mutual interdependence" (Agins 2006) in nondurable as well as durable manufacturing (Beckett 2009; Monget 2005; Rozhon 2005).

The opportunism problem is typically resolved, if it is resolved, by confidencebuilding measures and institutions, including trade associations, peak business organizations, cartels and cooperatives, mediation services, and alternative dispute resolution procedures. But, once again, the mere founding of such institutions hardly guarantees their effectiveness. As Soskice (1999:128) has observed, such measures are premised on effective business coordinating capacity, but "effective business coordinating capacity cannot generally be built 'spontaneously' to service an institutional framework." Rather, it requires that companies already "be engaged in long-term relational contracts" that can sustain "common shared understandings" and the "creation of expert communities across associations, research institutions, and companies" that "can only take place over long periods" (Soskice 1999:128).

Business coordinating capacity is not an unalloyed good, however, for it is no less conducive to rent-seeking and involution than to confidence building and relational contracting. Hall and Soskice therefore maintain that markets, like networks, function well only when properly institutionalized and that liberal market economies like the United States are well advised to embrace their disorganized business sectors by resolving market failures with "blunt" policy instruments - like deregulation and liberalization - that "do not put extensive demands on firms to form relational contracts with others" (Hall and Soskice 2001a:49) They recognize that this places industries like durable manufacturing that benefit from incremental innovation at a disadvantage, but they nonetheless argue that the costs are more than offset by the comparative advantages of freer market coordination for firms in industries like pharmaceuticals and biotechnology that are prone to "radical innovation."

If network failure is complete, Hall and Soskice are perhaps correct to give marketmaking priority over confidence-building. When network failure is partial, however, as in contested networks, this is by no means obvious. As in the case of involution, the glass is half full. Moving toward ideal-typical network coordination is not easy, but nor is it hopeless.

Take, for example, the durable manufacturing networks discussed by Whitford (2005). Manufacturers and their suppliers have intertwined their operations in order to take advantage of dispersed competencies, but they are unable to sustain the degree of joint problem solving and information sharing required for ideal-typical network governance. At the same time, however, because these failures are rooted in disputes internal to the companies in question, and because the players have a common interest in maintaining their collective competencies, there are common shared understandings that can be leveraged to build business coordinating capacity, which can itself be used to mitigate opportunism.

Whitford (2005; see also Whitford and Zeitlin 2004) outlines this strategy using a case study of the Wisconsin Manufacturers' Development Consortium (WMDC). The WMDC was initially established as a consortium of seven durable manufacturers forged with the support of a publicly funded industrial extension agency. It was in a sense designed simply to ensure the growth of competencies in component supply firms. However, by delivering training and consultancy services around issues like cost and inventory reduction, delivery and cycle times, and product quality through 
a public-private partnership, the consortium sought to use the parties' joint interest in maintaining competencies to mitigate opportunism in a number of different ways.

First, membership in the consortium served as a signal of the buyer's commitment to the collaborative model and thereby undercut suspicions on the part of component suppliers. Second, extension agents could serve as "honest brokers" to their associates in the WMDC and thereby ameliorate buyer-supplier conflict when it did arise. Third, the consortial structure encouraged collective investment in human resource and supplier upgrading and thereby helped resolve the free-rider problem that otherwise might have inhibited their growth. While by no means eliminating contestation, interventions of this sort help collaborationist factions in both buyer and supplier firms to work together across fluid organizational boundaries to face down opposition from marketeer factions in their home organizations.

The point is most assuredly not to belittle the problems faced by durable manufacturers in Wisconsin and the Upper Midwest. Indeed, the WMDC itself, while underscoring the opportunities for productive solutions, also illuminates the many obstacles to their success. The original consortium was supplanted first by a smaller subset of its members who sought to work much more intensely with suppliers than did the original consortium, and was then replaced by a looser but larger set of large manufacturers who have devolved elements of their supplier-development to the extension agency without the governance role they had in the original consortium. Nonetheless, our point stands. The existence and potential tractability of these problems lie in the fact that the region continues to play host to enormous competencies. The very competencies that are compromised by opportunism and bad faith, in fact, give their bearers an incentive to combat such behaviors, though their willingness and ability to do so are sharply circumscribed by organizational culture and government policy.

Nor are mediation and extension programs unique. Public officials can build confidence - and combat contestation - with regulatory sticks as well as promotional carrots. For example, the Securities and Exchange Commission is pursuing apparel buyers who impose "excessive" penalties on their suppliers (Barbaro 2007), and the Sarbanes-Oxley Act imposes new accounting and disclosure requirements that render such abuses more transparent and in so doing alters corporate incentive structures more generally (Jensen and Dube 2007). "You may see some retailers revise their processes," notes one apparel industry insider, "which would provide an opportunity for collaboration between them and vendors" (Women's Wear Daily 2005).

In other words, the government is in many cases not so much combating market failure (e.g., by breaking up abusive oligopolies) as it is combating network failure (e.g., by righting a temporary imbalance in power between buyers and suppliers involved in long-term, reciprocal exchange). While the consequences of such interventions are potentially profound, they are unlikely to be fully realized by policymakers who lack a "conceptual tool kit" (Powell 1990:301) with which to make sense of their own activities. Current efforts to rectify network failures are ad hoc and uncoordinated, in fact, precisely because policymakers lack such a toolkit (Schrank and Whitford 2009).

\section{IMPLICATIONS}

Network governance is functional in organizational fields characterized by unstable demand, dispersed and rapidly changing knowledge, and complex interdependencies 
between component technologies. But it may nonetheless fail in those fields, and it does so when exchange partners either screw each other or screw up. They are more likely to screw each other when formal and informal institutions fail to inhibit opportunism; they are more likely to screw up when such institutions fail to facilitate the search for new information beyond the network. When the institutions in question simultaneously inhibit opportunism and facilitate search, network governance becomes viable - at least insofar as technological and demand conditions render it desirable. However, when such institutions neither mitigate opportunism nor facilitate search, network production is all but impossible and stillbirth or devolution-that is, absolute network failure-occurs.

Table 1 distills our proposed theory into an admittedly stylized bivariate account of the four possible outcomes entailed by our propositions and subsidiary propositions. It does so in part by treating opportunism and ignorance, which are clearly continuous variables, as discrete for expository purposes. First, ideal-typical networks like the ones identified in the northwestern quadrant presuppose institutions that engender a search for new information and safeguards against opportunism among existing or potential exchange partners. Second, absolute network failures like the ones found in the southeastern quadrant occur when actors are embedded in institutions that provoke a combination of ignorance of relevant information and opportunism among existing or potential exchange partners. Third, involution is an outgrowth of ignorance and competency shortfalls and occurs largely due to isolation of various sorts, as in the cases identified in the southwestern quadrant. And, fourth, contested collaborations like the ones found in the northeastern quadrant are products of opportunistic behavior among otherwise competent partners.

Most students of organizational behavior assume that network governance goes from strength-to-strength or, conversely, weakness-to-weakness, and to the extent that they recognize the possibility of network failure, therefore, they tend to do so in terms of the southeastern quadrant. Williamson, for example, anticipated cascades of disturbances that would render network governance increasingly "nonviable" and foster a retreat to markets and hierarchies - over time (Williamson 1991:291). And Hall and Soskice (2001a:33) questioned whether network governance would often get off the ground in an economy beholden to weakly organized business and labor associations and a legal system, like the American one, that "militates against relational contracting." Much of our focus has therefore been on the "discordant" northeastern and southwestern cells, where we have endeavored to illuminate not only the possibility but the origins and characteristics of different types of relative network failures. Because those cells have received so little attention in the literature, however, we have been forced to demonstrate the plausibility of our last three propositions by putting a number of distinct studies into dialogue with each other. Future studies could assess the broader value of our framework by testing each of our propositions more thoroughly.

The essential question that remains, of course, is what difference it makes to draw these distinctions and test these propositions. That is, what do we gain from incorporating into our analyses of network governance an understanding of network failure not as the absence of network governance but in terms that recognize imperfection, and that therefore more closely equate to more established understandings of market and organizational failure?

Contemporary efforts to portray network arrangements neither as hybrid varieties nor as a residual category but as "a distinctive form of coordinating economic activity" (Powell 1990:301) have a number of laudable aspects, not least of all that 


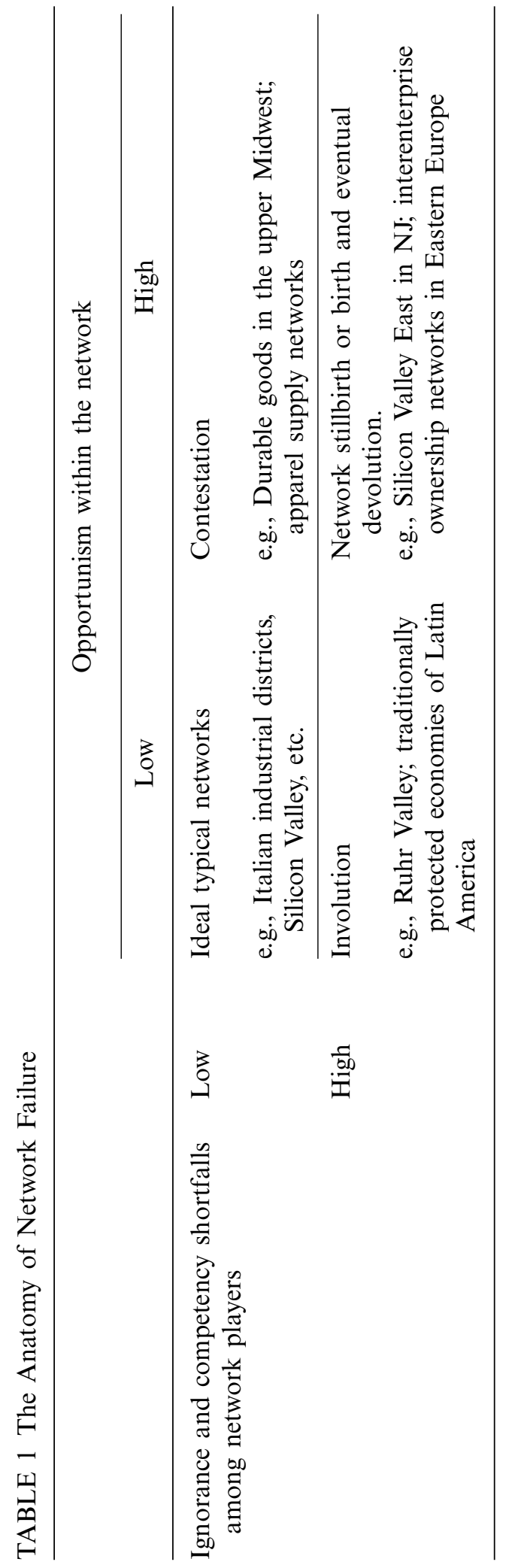


they accord with the beliefs and practices of actors who are party to the transactions themselves. Qualitative interviews carried out by a host of different investigators in a variety of different regional, national, and industrial contexts suggest that investors and managers draw an explicit distinction between "special" relationships and "oneshot" deals, and that they are well aware of at least the situational merits of the former (Uzzi 1996:677; see also Lorenzoni and Lipparini 1999; Schrank 2004; Shane and Cable 2002; Whitford 2005).

However, analysts of network production tend to treat the character of relationships (i.e., special or one-shot) as their explanans rather than their explanandum, and therefore devote almost all of their attention to the northwestern quadrant. While such studies do have their place - it is important to show that collaborative ties can be functional given particular exchange conditions - they provide a decidedly selective portrait of the realty they are designed to capture and therefore leave a key puzzle unanswered. If the potential parties to special relationships are in fact "aware of the benefits deriving from partnering and networking" (Lorenzoni and Lipparini 1999:331), why are they so reluctant to partner and network? Why do so many relationships go belly up in short order or underperform over the long run? And, more importantly, what does it mean that they do?

Answering these questions - if that answer is not to be tainted by selection bias or by measurement error-requires a conceptual schema that can distinguish the disappearance of particular organizations involved in networks from the failure of network governance writ large. Take, for example, a potential methodological shortcoming in Brian Uzzi's (1996, 1997) study of interorganizational relationships in the New York City garment industry. In the previous section, we cited that study as a key exploration of involution, which, on balance, we believe it to be. In his quantitative analysis, however, Uzzi regresses organizational mortality on network characteristics. And while rates of organizational mortality may be a good proxy for network performance (see, e.g., our discussion of the Mexican furniture cluster), they need not be. It is one thing to talk about what is good for a particular organization and quite another to talk about what is functional for actors entwined in social relations - particularly in the fast-moving and prototypically decentralized garment industry. In decentralized production models, after all, "workers and employers often trade places" (Sabel and Zeitlin 1985:174), and network relationships therefore tend to survive as well as anticipate their organizational foundations. "A New York City garment firm may die out with a family," according to Michael Piore and Charles Sabel (1984:269), "and an individual entrepreneur may drop back for a time into the ranks of the employees, but cultural and family ties make it unlikely that anyone who has begun working in the industry will leave it" (see also Schrank 2004; Waldinger 1984). ${ }^{3}$

Nor is the apparel industry unique. The "flexible recycling" of interpersonal relationships occurs daily in Silicon Valley, for example, and ensures that entrepreneurial "life after death" is not only common but commendable (Bahrami and Evans 1995:63; see also Child and McGrath 2001:1138). And Arthur Stinchcombe (1962:612) warns sociologists who might otherwise equate exit and failure that "in whole areas of the economy, for instance, the subcontracting trades in construction, frequently entering and leaving business is merely a normal device for maximizing return."

\footnotetext{
${ }^{3}$ Leaving the network that produced the industry may be even less likely. For example, the Dominican apparel makers analyzed by Schrank have responded to the challenge of low-cost Asian competition in part by redeploying their capital into collaborative ventures in other industries (Schrank 2008:24).
} 
Nor need ruptured relationships imply network failure. Indeed, as Powell et al. (2005:1187) show in their longitudinal study of network dynamics in biotechnology industries, a healthy network may in fact require that some ties or transactional streams be discontinuous. In such fast-paced industries, they write, "the frequent rewiring of attachments means that participants have to learn now to exit from relationships gracefully so as not to damage future prospects for affiliation."

The challenge of identifying not just why so many organizations and/or relationships disappear or are broken, but, more importantly, what it means when they do therefore requires careful consideration of the fact that network governance is not merely reducible to continuous relations between transactors but must be identified instead by the character of those relations. It demands attention to the boundaries between network and organizational failure. And, perhaps most importantly, when the question becomes one of analyzing the relative performance of network governance vis-à-vis alternative governance forms, it is essential to avoid either throwing underperforming networks out of the denominator or wrongly including failed organizations in the numerator.

Our approach to network failure guards against such problems. But that is not all. It also identifies network forms of governance in institutional terms, shows that the causes and the effects of those forms vary systematically, and underscores that sociologists can and should work out the power and limits not just of markets and hierarchies, but of networks as well. It therefore opens a range of new questions of substantial theoretical and practical importance. When are relative network failures remediable? When do they give way to devolution? And why? Do institutions like legal systems, corporate governance arrangements, and training regimes influence the quality as well as the quantity of network governance? Does national culture play a role? And do the answers vary by industry? How, if at all, do organizational structures, cultures, and compositions influence the likelihood and type of network failure? And does network structure influence the likelihood and/or character of network performance?

Answers to questions like these will not come easily. On the contrary, they demand: fine-grained observations of particular individuals, organizations, and environments; insights drawn from history, geography, statistics, and psychology; formal analyses of structural network data; and a deep-seated aversion to both economic reductionism, on the one hand, and market fetishism, on the other. But the payoff is likely to be enormous. The absence of a full-fledged theory of network failure that can stand beside theories of market and organizational failure has left significant gaps in our understanding of a mode of resource allocation - the network - that is neither less common nor less consequential than market exchange and organizational fiat. It is time those gaps were filled.

\section{REFERENCES}

Adams, Stephen B. 2003. "Regionalism in Stanford's Contribution to the Rise of Silicon Valley." Enterprise and Society 4:521-43.

Agins, Teri. 2006. "Boss Talk: Fashion Redesigner; Liz Claiborne CEO Charron Says the Apparel World Needs Less 'Art,' More 'Business'.” Wall Street Journal February 6, p. B1.

Amin, Ash and Kevin Robins. 1990. "The Re-Emergence of Regional Economies? The Mythical Geography of Flexible Accumulation.” Environment and Planning D: Society and Space 8:7-34.

Appold, Stephen. 1995. "Agglomeration, Interorganisational Networks, and Competitive Performance in the US Metalworking Sector." Economic Geography 71:27-54. 
Arrow, Kenneth. 1970. "The Organization of Economic Activity: Issues Pertinent to the Choice of Market Versus Nonmarket Allocation.” Pp. 59-73 in Public Expenditures and Policy Analysis, edited by Robert Haveman and Julius Margolis. Chicago: Markham Publishing Company.

Bahrami, Homa and Stuart Evans. 1995. "Flexible Re-Cycling and High-Technology Entrepreneurship." California Management Review 37:62-89.

Barbaro, Michael. 2007. "Saks Settles with S.E.C. on Overpayments." New York Times September 6, p. C12.

Barnard, Chester. [1938] 1968. The Functions of the Executive. Cambridge, MA: Harvard University Press. Bator, Francis. 1958. "The Anatomy of Market Failure." Quarterly Journal of Economics 72:351-79.

Beckett, Whitney. 2009. "Vendors Ally with Retailers, as Economy Besieges Both." Women's Wear Daily March 18, p. 8.

Berling, Robert J. 1993. "The Emerging Approach to Business Strategy: Building a Relationship Advantage." Business Horizons 36:16-27.

Bird, Laura and Wendy Bounds. 1997. "Stores' Demands Squeeze Apparel Companies." Wall Street Journal July 15, p. B1.

Blackford, Mansel. 2007. Pathways to the Present: U.S. Development and its Consequences in the Pacific. Honolulu: University of Hawaii Press.

Block, Fred. 2003. "Karl Polanyi and the Writing of The Great Transformation." Theory and Society 32:275-306.

Branch, Anthony. 1985. "Silicon Valley Fever." California Management Review 27:158-60.

Brusco, Sebastiano. 1982. "The Emilian Model: Productive Decentralisation and Social Integration." Cambridge Journal of Economics 6:167-84.

_. 1999. "The Rules of the Game in Industrial Districts." Pp. 17-40 in Interfirm Networks: Organization and Industrial Competitiveness, edited by Anna Grandori. New York: Routledge.

Brusoni, Stefano and Andrea Prencipe. 2001. "Unpacking the Black Box of Modularity: Technologies, Products and Organizations." Industrial and Corporate Change 10:179-205.

Brusoni, Stefano, Andrea Prencipe, and Keith Pavitt. 2001. "Knowledge Specialization, Organizational Coupling, and the Boundaries of the Firm: Why Do Firms Know More Than They Make?" Administrative Science Quarterly 46:597-621.

Chain Store Age. 2003. "Managing the Trading-Partner Link Is the Key to Success." Chain Store Age 79:2A-12A.

Child, John and Rita Gunther McGrath. 2001. "Organizations Unfettered: Organizational Form in an Information-Intensive Economy." Academy of Management Journal 44:1135-48.

Cooke, Philip. 2000. "Review of Michie, J. and Grieve Smith, J., editors, 1998: Globalization, Growth, and Governance (Oxford: Oxford University Press)." Progress in Human Geography 24:160-61.

Danaher, Tim. 2006. "Suppliers and Retailers Joined at the Hip." Retail Week December 8.

DiMaggio, Paul. 1989. "Foreword." Pp. 9-11 in Permanently Failing Organizations, edited by Marshall Meyer and Lynn Zucker. Newbury Park, CA: Sage Publications.

DiMaggio, Paul and Walter Powell. 1983. "The Iron Cage Revisited: Institutional Isomorphism and Collective Rationality in Organizational Fields.” American Sociological Review 48:147-60.

Dore, Ronald. 1983. "Goodwill and the Spirit of Market Capitalism.” British Journal of Sociology 34:45982.

Dorf, Michael and Charles Sabel. 1998. "A Constitution of Democratic Experimentalism.” Columbia Law Review 98:267-473.

Economist. 1995. "Airline Alliances: Flying in Formation.” Economist 336:59-60.

Financial Times. 2007. "Happily Never After Merger, Like Marriages, Fail Without a Meeting of the Minds." Financial Times May 15, p. 14.

Geertz, Clifford. 1963. Peddlers and Princes: Social Development and Economic Change in Two Indonesian Towns. Chicago: University of Chicago Press.

Gilson, Ronald, Charles Sabel, and Robert Scott. 2009. "Contracting for Innovation: Vertical Disintegration and Interfirm Collaboration." Columbia Law Review 109:431-502.

Grabher, Gernot. 1993. "The Weakness of Strong Ties: The Lock-In of Regional Development in the Ruhr Area." Pp. 255-77 in The Embedded Firm: On the Socioeconomics of Industrial Networks, edited by Gernot Grabher. New York: Routledge.

Granovetter, Mark. 1985. "Economic Action and Social Structure: The Problem of Embeddedness." American Journal of Sociology 91:481-510.

- 1990. "The Old and the New Economic Sociology: A History and an Agenda." Pp. 89-112 in Beyond the Marketplace: Rethinking Economy and Society, edited by Roger Friedland and A. F. Robertson. Hawthorne, NY: Aldine De Gruyter.

Håkanson, Lars. 2005. "Epistemic Communities and Cluster Dynamics: On the Role of Knowledge in Industrial Districts." Industry and Innovation 12:433-63. 
Hall, Peter and David Soskice. 2001a. "Introduction." in Varieties of Capitalism: The Institutional Foundations of Comparative Advantage, edited by Peter Hall and David Soskice. Oxford: Oxford University Press.

- 2001b. Varieties of Capitalism: The Institutional Foundations of Comparative Advantage. Oxford: Oxford University Press.

Hannan, Michael and John Freeman. 1977. "The Population Ecology of Organizations." American Journal of Sociology 82:929-64.

Harrison, Bennett. 1994. Lean and Mean. New York: Basic Books.

Hays, Constance. 2001. Big Stakes in Small Errors. New York: New York Times.

Helper, Susan, John Paul MacDuffie, and Charles Sabel. 2000. "Pragmatic Collaborations: Advancing Knowledge While Controlling Opportunism.” Industrial and Corporate Change 9:443-83.

Hendry, John. 2002. "The Principal's Other Problems: Honest Incompetence and the Specification of Objectives." Administrative Science Quarterly 27:98-113.

Herrigel, Gary. 2004. "Emerging Strategies and Forms of Governance in the Components Industry in High Wage Regions." Industry and Innovation 11:45-80.

Hill, Charles. 1990. "Cooperation, Opportunism, and the Invisible Hand: Implications for Transactions Cost Theory." Academy of Management Review 15:500-13.

Hospers, Gert-Jan. 2006. "Silicon Somewhere? Assessing the Usefulness of Best Practices in Regional Policy." Policy Studies 27:1-15.

Hughes, John. 1998. "Chrysler, Daimler Merger Could Reshape Auto Industry.” Toronto Sun May 10, p. D13.

Human, Sherrie and Keith Provan. 2000. "Legitimacy Building in the Evolution of Small-Firm Networks: A Comparative Study of Success and Demise." Administrative Science Quarterly 45:327-65.

Jensen, Amber and Sema Dube. 2007. "Trickle-Down Effect of the Sarbanes-Oxley Act on a PrivatelyHeld Seasonal Textile Manufacturer.” Journal of Business Case Studies 3:45-50.

Jones, Candace, William Hesterly, and Stephen Borgatti. 1997. "A General Theory of Network Governance: Exchange Conditions and Social Mechanisms." Academy of Management Review 22:911-45.

King, Lawrence. 2001. "Making Markets: A Comparative Study of Postcommunist Managerial Strategies in Central Europe." Theory and Society 30:493-538.

Kivimaa, Paula and Per Mickwitz. 2004. "Driving Forces for Environmentally Sounder Innovations: The Case of the Finnish Pulp and Paper Industry." Pp. 356-72 in Governance for Industrial Transformation: Proceedings of the 2003 Berlin Conference on the Human Dimensions of Global Environmental Change, edited by Klaus Jacob, Manfred Binder, and Anna Wieczorek. Berlin: Environmental Policy Research Center.

Kogut, Bruce. 1989. "The Stability of Joint Ventures: Reciprocity and Competitive Rivalry." Journal of Industrial Economics 38:183-98.

Krippner, Greta. 2001. "The Elusive Market: Embeddedness and the Paradigm of Economic Sociology." Theory and Society 30:775-810.

Krippner, Greta, Mark Granovetter, Fred Block, Nicole Biggart, Tom Beamish, Youtien Hsing, Gillian Hart, Giovanni Arrighi, Margie Mendell, John Hall, Michael Burawoy, Steve Vogel, and Sean O'Riain. 2004. "Polanyi Symposium: A Conversation on Embeddedness." Socio-Economic Review 2:109-35.

Laumann, Edward O, Joseph Galaskiewicz, and Peter Marsden. 1978. "Community Structure as Interorganizational Linkage." Annual Review of Sociology 4:455-84.

Leslie, Stuart and Robert Kargon. 1996. "Selling Silicon Valley: Frederick Terman's Model of Regional Advantage." Business History Review 70:435-72.

Levitt, Barbara and James March. 1988. "Organizational Learning." Annual Review of Sociology 14: 319-38.

Lorenzoni, Gianni and Andrea Lipparini. 1999. “The Leveraging of Interfirm Relationships as a Distinctive Organizational Capability: A Longitudinal Study.” Strategic Management Journal 20:317-38.

MacDuffie, John Paul and Susan Helper. 2006. "Collaboration in Supply Chains: With and Without Trust." Pp. 417-66 in Collaborative Community, edited by Charles Heckscher and Paul Adler. Oxford: Oxford University Press.

Marceau, Jane. 2005. "Why Can't We All Have a Silicon Valley?" Australian Review of Public Affairs December 12. Retrieved June 8, 2011 (http://www.australianreview.net/digest/2005/12/marceau.html).

McEvily, Bill and Alfred Marcus. 2005. "Embedded Ties and the Acquisition of Competitive Capabilities." Strategic Management Journal 26:1033-55.

McLaughlin, Abraham. 1999. "Reinventing the Rust Belt-With Microchips." Christian Science Monitor May 12. p. 1.

Mellewigt, Thomas, Anoop Madhok, and Antoinette Weibel. 2007. "Trust and Formal Contracts in Interorganizational Relationships-Substitutes and Complements." Managerial and Decision Economics 28:833-47. 
Meyer, Marshall and Lynne Zucker. 1989. Permanently Failing Organizations. Newbury Park, CA: Sage Publications.

Monget, Karyn. 2005. "Retail Squeeze Gets Tighter.” Women's Wear Daily 189.

Nahapiet, Janine and Sumantra Ghoshal. 1998. "Social Capital, Intellectual Capital, and the Organizational Advantage." Academy of Management Review 23:242-66.

Natali, Anna. 2007. "Introduzione, Parte Seconda: Politiche per le Piccole Imprese e per lo Sviluppo Locale." Pp. 191-207 in Distretti Industriali e Sviluppo Locale, edited by Anna Natali, Margherita Russo, and Giovanni Solinas. Bologna: Il Mulino.

Park, Seung Ho and Michael Russo. 1996. "When Competition Eclipses Cooperation: An Event History Analysis of Joint Venture Failure.” Management Science 42:875-90.

Pierce, John R. and Arthur Tressler. 1964. The Research State: A History of Science in New Jersey. Princeton, NJ: Van Nostrand.

Piore, Michael, Yevgeni Kuznetsov, Clemente Ruíz Duran, and Charles Sabel. 2001. "Think Globally, Act Locally: Decentralized Incentive Framework for Mexico's Private Sector Development." World Bank Informal Research Report.

Piore, Michael and Charles Sabel. 1984. The Second Industrial Divide: Possibilities for Prosperity. New York: Basic Books.

Podolny, Joel. 2001. "Networks as the Pipes and Prisms of the Market." American Journal of Sociology 107:33-60.

Podolny, Joel and Karen Page. 1998. "Network Forms of Organization." Annual Review of Sociology 24:57-76.

Powell, Walter. 1990. "Neither Market Nor Hierarchy: Network Forms of Organization.” Pp. $295-336$ in Research in Organizational Behavior, Vol. 12, edited by Barry Staw and Larry L. Cummings. Greenwich, CT: JAI Press.

- 2001. "The Capitalist Firm in the Twenty-First Century: Emerging Patterns in Western Enterprise." Pp. 3-30 in The Twenty-First-Century Firm: Changing Economic Organization in International Perspective, edited by Paul DiMaggio. Princeton, NJ: Princeton University Press.

Powell, Walter W., Douglas White, Kenneth Koput, and Jason Owen-Smith. 2005. "Network Dynamics and Field Evolution: The Growth of Interorganizational Collaboration in the Life Sciences." American Journal of Sociology 110:1132-1205.

Rooks, Gerrit, Werner Raub, Robert Selten, and Frits Tazelaar. 2000. "How Inter-Firm Co-Operation Depends on Social Embeddedness: A Vignette Study." Acta Sociologica 43:123-37.

Rozhon, Tracie. 2005. "First the Markdown, Then the Showdown." New York Times February 25, p. C1.

Ruiz Durán, Clemente. 1998. "Clustering: Joint Learning Experience.” Facultad de Economia, Working Paper, Universidad Autonoma de Mexico.

Sabel, Charles. 1993. "Studied Trust: Building New Forms of Cooperation in a Volatile Economy." Human Relations 46:1133-70.

- 1994. "Learning by Monitoring: The Institutions of Economic Development.” Pp. 137-65 in The Handbook of Economic Sociology, edited by Neil Smelser and Richard Swedberg. Princeton, NJ: Princeton University Press.

Sabel, Charles and AnnaLee Saxenian. 2008. "A Fugitive Success: Finland's Economic Future." Sitra Reports, Helsinki.

Sabel, Charles and Jonathan Zeitlin. 1985. "Historical Alternatives to Mass Production: Politics, Markets and Technology in Nineteenth-Century Industrialization." Past-and-Present 108:133-76.

Sako, Mari. 1992. Prices, Quality and Trust: Inter-Firm Relations in Britain and Japan. Cambridge, UK: Cambridge University Press.

Schrank, Andrew. 2004. "Ready-to-Wear Development? Foreign Investment, Technology Transfer, and Learning-by-Watching in the Apparel Trade." Social Forces 83:123-56.

—. 2005. "Entrepreneurship, Export Diversification, and Economic Reform: The Birth of a 'Developmental Community' in the Dominican Republic." Comparative Politics 38:43-62.

—. 2008. "Homeward Bound: Interest, Identity, and Investor Behavior in a Third World Export Platform." American Journal of Sociology 114:1-34.

—. 2011. "Co-Producing Workplace Transformation: The Dominican Republic in Comparative Perspective.” Socio-Economic Review 9:419-46.

Schrank, Andrew and Josh Whitford. 2009. "Industrial Policy in the United States: A Neo-Polanyian Interpretation." Politics \& Society 37:521-53.

Shane, Scott and Daniel Cable. 2002. "Network Ties, Reputation, and the Financing of New Ventures." Management Science 48:364-81.

Shields, Amy 2009. "Between a Rock and a Hard Place." Retail Week June $5 . \quad$ Retrieved June 8, 2011 (http://www.retail-week.com/in-business/supply-chain/between-a-rock-and-ahard-place/5003306.article). 
Smith-Doerr, Laurel and Walter Powell. 2005. "Networks and Economic Life." Pp. 379-402 in The Handbook of Economic Sociology, Second Edition, edited by Neil Smelser and Richard Swedberg. Princeton, NJ: Princeton University Press.

Soskice, David. 1999. "Divergent Production Regimes: Coordinated and Uncoordinated Market Economies in the 1980s and 1990s." Pp. 101-34 in Continuity and Change in Contemporary Capitalism, edited by Herbert Kitschelt, Peter Lange, Gary Marks, and John Stephens. New York: Cambridge University Press.

Stark, David. 1993. "From System Identity to Organizational Diversity: Analyzing Change in Eastern Europe." Contemporary Sociology 21:299-304.

․ 1996. "Recombinant Property in East European Capitalism." American Journal of Sociology 101:993-1027.

Stark, David and Balàzs Vedres. 2006. "Social Times of Network Spaces: Network Sequences and Foreign Investment in Hungary." American Journal of Sociology 111:1367-1411.

Stinchcombe, Arthur. 1962. "Book Review of The First Two Years: Problems of Small Firm Growth and Survival (Mayer, Kurt and Sidney Goldstein)." American Journal of Sociology 67:611-12.

- 1990. Information and Organizations. Berkeley: University of California Press.

Streeck, Wolfgang and Philippe Schmitter. 1985. "Community, Market, State-And Associations? The Prospective Contribution of Interest Governance to Social Order." European Sociological Review 1:11938.

Tarrow, Sidney. 1996. "Making Social Science Work Across Space and Time: A Critical Reflection on Robert Putnam's Making Democracy Work.” American Political Science Review 90:389-97.

Thompson, Grahame. 2003. Between Hierarchies and Markets: The Logic and Limits of Network Forms of Organization. Oxford: Oxford University Press.

Uzzi, Brian. 1996. "The Sources and Consequences of Embeddedness for the Economic Performance of Organizations: The Network Effect." American Sociological Review 61:674-98.

_ 1997. "Social Structure and Competition in Interfirm Networks: The Paradox of Embeddedness." Administrative Science Quarterly 42:35-67.

von Tunzelmann, Nick. 2003. "Historical Coevolution of Governance and Technology in the Industrial Revolutions.” Structural Change and Economic Dynamics 14:365-84.

—. 2010. "Alignment, Misalignment and Dynamic Network-Based Capabilities." Pp. 3-22 in Network Dynamics in Emerging Regions of Europe, edited by David Dyker. London: Imperial College Press.

Waldinger, Roger. 1984. "Immigrant Enterprise in the New York Garment Industry." Social Problems 32:60-64.

Whitford, Josh. 2005. The New Old Economy: Networks, Institutions, and the Organizational Transformation of American Manufacturing. Oxford: Oxford University Press.

Whitford, Josh and Aldo Enrietti. 2005. "Surviving the Fall of a King: The Regional Institutional Implications of Crisis at Fiat Auto.” International Journal of Urban and Regional Research 29:771-95.

Whitford, Josh and Jonathan Zeitlin. 2004. "Governing Decentralized Production: Institutions, Public Policy, and the Prospects for Inter-Firm Collaboration in US Manufacturing." Industry and Innovation 11:11-44.

Williamson, Oliver. 1975. Markets and Hierarchies: Analysis and Antitrust Implications. New York: Free Press.

- 1985. The Economic Institutions of Capitalism. New York: Free Press.

—. 1991. "Comparative Economic Organization: The Analysis of Discrete Structural Alternatives." Administrative Science Quarterly 36:269-96.

1993. "Introduction." Pp. 3-17 in The Nature of the Firm: Origins, Evolution and Development, edited by Oliver Williamson and Sidney Winter. Oxford: Oxford University Press.

Women's Wear Daily. 2005. "Chargebacks Reform: Vendors Hope Probes Level the Playing Field." Women's Wear Daily June 7, pp. 1-17.

Zaheer, Srilata and Elaine Mosakowski. 1997. "The Dynamics of the Liability of Foreignness: A Global Study of Survival in Financial Services.” Strategic Management Journal 18:439-64. 